Юлия Эдуардовна ШУСТОВА

ORCID 0000-0002-0708-5591

\title{
Малоизвестные издания типографии Львовского Успенского Ставропигийского братства о праздновании Юбилейных годов (“Annus sanctus”) во Львовской епархии в XVIII в. Памяти профессора Игоря Скочиляса
}

Рассматриваются малоизвестные источники о праздновании Юбилейного года во Львовской епархии в XVIII веке - универсал епископа Афанасия Шептицкого 1722 г. и книга “Милостивое лето" (1776), напечатанные в типографии Львовского Успенского братства. Анализируется их структура и содержание в контексте окцидентальных тенденций в Грекокатолической церкви. Изучены вопросы библиографии не сохранившейся грамоты Львовского епископа Льва Шептицкого о праздновании Великого Юбилея 1776 г. и единственного известного экземпляра книги “Милостивое лето”, содержащей чинопоследования празднику. В приложении впервые публикуется полностью текст печатного бланка универсала Афанасия Шептицкого 1722 г.

Ключевые слова: типография Львовского братства, печатные бланки, кириллические издания, Львовская епархия, Афанасий Шептицкий, Лев Шептицкий, Юбилейный год

Юлія Едуардівна Шустова

Маловідомі видання друкарні Львівського Успенського Ставропігійського братства про святкування Ювілейних років (“Annus sanctus”) у Львівській спархії у XVIII ст.

Розглядаються маловідомі джерела про святкування Ювілейного року у Львівській єпарxiї в XVIII ст. Це випущені в друкарні Львівського Успенського Ставропігійського братства універсал Львівського єпископа Атанасія Шептицького 1722 р. і книга "Милостиве літо" (1776), а також грамота Львівського єпископа Льва Шептицького 1776 р., що не збереглась до нашого часу. Говориться про історію виникнення і побутування Ювілейного року (“Annus sanctus”) в старозавітній традиції і Римско-католицькій церкві. Вперше подано структуру змісту друкованого бланка універсалу львівського єпископа Атанасія Шептицького від 9 травня 1722 р. про святкування Ювілейного року і відпущення всіх гріхів тим парохіянам, які виконали приписи щодо його проведення. Єдиний відомий примірник цього видання зберігається в Центральному державному історичному архіві України у м. Львові. На підставі аналізу шрифтів і орнаментики документа зроблено висновок про місце його видання (Львів, друкарня братства), що не зазначено в тексті грамоти. Наведено висновки про значення єпископського послання в контексті зближення греко-католицького і латинського обрядів, а також про причини поганого збереження цього видання. Також вивчено питання бібліографії грамоти Львівського єпископа Льва Шептицького про святкування Великого Ювілею в 1776 р., яка не збереглася до сьогодні. Це видання було відоме бібліографам ХІХ ст., але сьогодні на- 
лежить до розшукуваних стародруків друкарні Львівського братства. Докладно розглянуто бібліографію книги “Милостиве літо” (Львів, 1776), простежено історію побутування єдиного відомого примірника, що зберігається в Російській державній бібліотеці. Детально описано і проаналізовано склад книги, що містить чинопослідування свята, коротку катехитичну частину, церковні пісні українською мовою. Зроблено висновки про значення розглянутих джерел для вивчення окцидентальних тенденцій у Греко-католицькій церкві у XVIII ст. У додатку вперше публікується повністю текст друкованого бланка універсалу Львівського єпископа Атанасія Шептицького 1722 p.

Ключові слова: друкарня Львівського братства, друковані бланки, кириличні стародруки, Львівська єпархія, Атанасій Шептицький, Лев Шептицький, Ювілейний рік

\section{Yuliya Shustova \\ Little-known publications of the printing house of the Lviv Dormition Stauropegion Brotherhood about the celebration of the Jubilee years ("Annus sanctus") in the Lviv eparchy in the 18th century}

The little-known sources about the celebration of the Jubilee Year ("Annus sanctus") in the Lviv diocese in the 18th century are analyzed. These are printed editions - the Universal of Lviv Bishop Athanasius Sheptytskyi in 1722 and the book "Milostivoye leto" ("Merciful summer") (1776), as well as the unpreserved letter of the Lviv Bishop Lev Sheptytskyi in 1776, printed in the printing house of the Lviv Dormition Stauropegion Brotherhood. It tells about the history of the emergence and existence of the Jubilee Year ("Annus sanctus") in the Old Testament tradition and the Catholic Church. For the first time, the structure and content of the printed form of the universal of Lviv Bishop Athanasius Sheptytskyi of 1722 about the celebration of the Jubilee Year and the absolution of all sins for those who fulfilled the instructions for its implementation are analyzed. The only known copy of this publication is kept in the Central State Historical Archives of Ukraine in Lviv. Based on the analysis of fonts and ornamentation of the publication, conclusions are drawn about the place of its publication. Conclusions are made about the significance of the bishop's letter in the context of the convergence of the Greek Catholic and Latin rites, as well as the reasons for the poor preservation of this edition. The questions of the bibliography of the not preserved letter of the Lviv Bishop Lev Sheptytskyi about the celebration of the Great Jubilee in 1776 were also studied. The publication was known to bibliographers of the 19th century, but today it belongs to the number of wanted editions of the Lviv Brotherhood printing house. The bibliography of the book "Milostivoye leto" ("Merciful summer") (Lviv, 1776) is considered in detail. The history of the existence of the only known copy, which is kept in the Russian State Library, is traced. The composition of the book is described and analyzed in detail, it contains rites for the holiday, a short catechetical part, church songs in Ukrainian. Conclusions about the significance of the sources considered for the study of occidental tendencies in the Greek Catholic Church in the 18th century are drawn. In the appendix for the first time the full text of the Letterheads of the Universal of the Lviv Bishop Athanasius Sheptytskyi in 1722 is published.

Keywords: printing house of the Lviv Dormition Stauropegion Brotherhood, Letterheads, Old Cyrillic editions, Lviv eparchy in the 18th century, Afanasy Sheptytskyi, Lev Sheptytskyi, “Annus sanctus"

Постановка проблемы. Типография Львовского Успенского Ставропигийского братства, будучи одним из крупнейших кириллических книгоиздательских центров, играла важную роль в истории и культуре украинских земель в конце XVI XVIII вв. Проблемам ее истории и библиографии посвящены многочисленные 
работы исследователей разных стран. Однако до сих пор остаются не изученными или обойденными вниманием разные аспекты книгопечатания, реконструкции репертуара изданий. Менее всего изучена деятельность типографии братства в унийный период. Ряд изданий не входили в поле зрения ученых в силу их малодоступности, плохой сохранности.

Изучение этих изданий в контексте окцидентализации униатской церкви в XVIII в. и истории украинского книгоиздания является актуальной задачей в изучении истории и культуры Украины XVIII в., истории церкви и книжного дела, проблем библиографии.

В данной работе рассматриваются два издания типографии Львовского братства, разные по своей видовой принадлежности, но связанные одной тематикой. Это - универсал Львовского епископа Афанасия Шептицкого 1722 г. о праздновании Юбилейного года во Львовской епархии и книга "Милостивое лето, или Благопотребных молений к душеполезному лета оставления провождению” (Львов, тип. Братства, июнь 1776). Оба издания посвящены празднованию так называемого Юбилейного года. Первое впервые было введено в научный оборот в 2010 г. Игорем Скочилясом в монографии "Галицкая (Львовская) епархия XII-XVIII вв.: организационная структура и правовой статус"). Однолистное издание было им выявлено в фонде “Львовская греко-католическая митрополичья консистория, г. Львов” в Центральном государственном историческом архиве Украины в г. Львове. Книга “Милостивое лето” известна в библиографии с 1879 г., когда ее описал Ф. Н. Добрянский в “Путеводителе по Виленской публичной библиотеке”. Впоследствии ее упоминали в каталогах книг другие библиографы. Единственный известный экземпляр этого издания хранится в собрании Российской государственной библиотеки. Таким образом, оба издания на сегодняшний день представлены единственными экземплярами, дошедшими до наших дней. К числу изданий, посвященных празднованию Юбилейного года, следует отнести издание, описанное в библиографии, но сегодня относящееся к разыскиваемым изданиям. Это грамота Львовского епископа Льва Шептицкого от 30 апреля 1776 о праздновании “Вселенского Ювелиона”.

Цель данной работы - проанализировать издания типографии Львовского братства, увидевшие свет в связи с введением нового для униатской церкви обряда, позаимствованного в католической церкви - Юбилейного года. Рассматриваться они будут в контексте истории обрядовой культуры и библиографии изданий XVIII в.

\section{Изложение основного материала}

Практика отмечать Юбилейный год уходит корнями в иудейскую ветхозаветную традицию. В еврейском календаре существовала практика отмечать особые празднования - субботний и юбилейный годы. Год субботний составлял семилетний календарный цикл, т. е. отмечался каждый седьмой год (Лев. 25: 1-7). Земле в этот год следовало давать отдых, прекращать земледелие, а людям в “год прощения” прощались все грехи. После цикла в семь субботних лет наступал 
Юбилейный год, совершавшийся в каждый пятидесятый год (Лев. 25: 8). Слово “юбилей” происходит от древнееврейского “jôbêl”, что означало “бараний рог”, “труба". В ознаменование провозглашения юбилейного года, который отмечали в десятый день седьмого месяца, трубили в бараний рог - “шофар” (Лев. 25: 9). В юбилейный год обычаи субботнего года отмечались более масштабно, и прощение грехов становилось важнейшим в праздновании всеобщего обновления - природы и человека (Исх. 23: 10-11; Лев. 25: 10-55; Втор. 15: 1-18).

В Римско-католической церкви традицию отмечать Юбилейный год - “Annus sanctus" - ввел папа Бонифатий VIII. 22 февраля 1300 г. он издал буллу “Antiquorum habet fide", в которой объявлялось о провозглашении Юбилейного (“святого”) года в честь Святых апостолов Петра и Павла в наступающем 1300 году; о полном отпущении всех грехов (индульгенции) всем, кто в полном раскаянии и после исповедания всех своих грехов (“indulgentiam plenariam”), причащения Св. Тайн, совершения паломничества в Рим и посещения четырех главных храмов - Собора Св. Петра, Латеранской базилики, церквей Санта-Мария Маджоре и Сан-Паоло - или к другим святыням католической церкви, будет совершать в них молитвословия, специально определенные для этого. Юбилейные годы следовало отмечать каждые сто лет, т. е. следующими такими годами должны были быть годы 1400, 1500 и т. д. [1, с. 220-221]. Юбилейный год должен был служить духовному очищению верующих благодаря дарованию папой полного отпущения грехов и прочих духовных милостей.

Юбилейный год не только сулил отпущение грехов, но и приносил существенные финансовые выгоды церкви. Стремление сделать Юбилейный год доступным для каждого человека любого возраста и достатка (не всегда способного оплатить паломничество в Рим), а также финансовые преференции побуждали пап XIV-XV вв. сокращать сроки проведения “Annus sanctus”, а также выдавать привилегии тем или иным духовным учреждениям, посещение которых приравнивалось к паломничеству в Рим [13, с. 469-470]. В 1343 г. папа Климент VI в булле "Unigenitus Dei Fillius" сократил время между Юбилейными годами до 50 лет, т. е. следующим таким годом стал 1350 г. Папа Урбан VI в 1389 г. установил празднование юбилея в 33-летний период - возраст земной жизни Христа. Однако из-за его смерти в этом году Юбилей был отпразднован папой Бонифацием IX в 1390 г., а через десять лет торжество было повторено. Бонифаций IX стал вводить практики празднования Юбилейного года в поместных церквях. Папа Павел II в 1470 г. определил празднование “Annus sanctus” каждые 25 лет [1, с. 222-224]. Начиная с 1585 г., следуя Сиксту V, папы нередко провозглашали юбилейное отпущение грехов, как правило, в течение 30 дней, по случаю их избрания на папский престол [20].

В 1721 г. новым папой был избран Иннокентий III. На следующий день после выборов, 27 мая 1721 г., понтифик объявил “Annus sanctus”. Именно этот Юбилейный год впервые отмечался в греко-католической Львовской епархии. Это заимствование католического обряда было одним из элементов постепенной 
окцидентализации обрядовых и литургических практик. В их числе, как отмечал И. Я. Скочиляс, был рост популярности индульгенций. Несмотря на то, что они были известны в православной церковной практике еще с ХІ в., именно Римский престол санкционировал их введение в греко-католической церкви, максимально сближая их с латинским обрядом [1, с. 307-308].

Инициатором таких продуманных и осторожных нововведений был Львовский епископ Афанасий Шептицкий. Он издал универсал (пастырское послание) о праздновании Юбилейного года во Львовской епархии в 1722 г. В документе говорилось о причинах этого празднования, объяснялось, что такое “Юбилеуш" и определялись формы его проведения с целью получения отпущения грехов.

В преамбуле универсала говорится о том, что утвердил празднование Юбилейного года (“Юбъліеуша”) папа Римский Иннокентий XIII. Юбилейный год, объясняется в послании, - это “Льто благодати и милости Божой”. И рассматривается он как соединение Восточной и Западной церквей: “съ Церквїю Въсточною и Заходною съединенныћ, и истиннаго в житїи исправленїА, до разширенї^ въры православно каөолической, къ соединенїю Св. Божіих Церквїи” с целью преодоления и прощения общих для всех христиан проблем: “ съвђтовъ, $\omega$ оугашенїи вслких любопрђнїи, а запаленА ФгнА любвие и згоды: между правовЊрными цары и кнАSы: $\omega$ избавленїи вслкаго праведнаго прощенї^ Божел: яко то: войны, повђтрА, и вслкї^ смертоносныА раны благоутробїемъ подвыженный възбуждаеть" [14, л. 1].

Чтобы получить прощение грехов, со времени провозглашения Юбилейного года, христиане должны соблюдать следующие правила (кондиции).

Во-первых, соблюдать пост “сухолденїемъ” в понедельник, среду и пятницу спустя неделю после объявления Юбилейного года и на протяжении двух седмиц.

Во-вторых, следует посетить три главные церкви во Львове - епископскую кафедральную (Св. Юра), городскую (“МҺсцкую”) Успенскую и на Краковском предместье Св. Николая. Посетить церкви можно было как в один день или на протяжении нескольких и в каждой перед алтарем совершать молитвы “Отче наш" и "Богородице Дево" - по пять раз каждую, а также другие молитвы, в т.ч. за папу Иннокентия XIII, “О разоренїи ересей, разширенїи же вђры Святой Каөолической; о оумноженїи Православных Христїлн, о избавленїи вслкаго гнђва

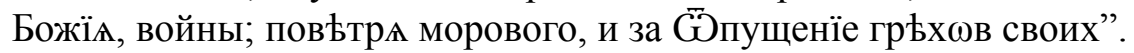

В-третьих, в других городах, местечках и селах, в которых имеется только одна церковь, совершать молитвы перед алтарем и другими иконами, повторив их сполна трижды.

В-четвертых, говорилось о полном отпущении грехов после исповеди, освобождении от всяких “запрещений” и обязательств, или примирения двух конфликтующих сторон (“з сторонами оукривжоными згодит”), за исключением споров, касающихся профессиональной деятельности (“Фпроч Законной Профессїи”). 
В-пятых, говорилось о необходимости раздавать пожертвования всем, нищим и страждущим, а также воздержания от увеселений, судебных тяжб и пр. (““可 музикъ, Танцовъ, бесьдъ непотребныхъ, $\bar{G}$ позвовъ, и вшелАкой съ ближным незгоды, въздержатисл"). Все, кто выполнит указанные кондиции после исповеди и причащения, получит отпущение всех грехов (“кто теи кондицїи виполнитъ,

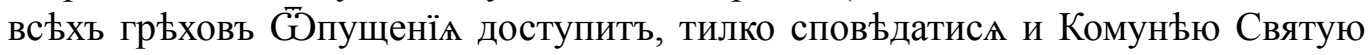
принАти потреба") [14, л. 1].

В связи с тем, что суть нововведения и порядок его исполнения следовало донести до всех священнослужителей и мирян, то послание Афанасия Шептицкого было издано печатным способом. По своей форме - это однолистное издание, напечатанное на одной стороне и представляющее собой бланк, т. е. такую печатную форму, в которой оставлялись пробельные места для того, чтобы вписать в них текст от руки. В данном случае пробельные места были оставлены для заполнения даты публичного объявления универсала в каждом конкретном приходе, куда поступал документ.

В типографии Львовского братства печатали бланки, в том числе разрешительные грамоты, начиная с конца XVI в. [15, с. 463-467; 18, с. 639-656; 19, с. 215-243]. Как правило, листовые издания, особенно бланки, плохо сохраняются в силу специфики своего предназначения и использования. Рассматриваемый универсал Афанасия Шептицкого относится именно к таким документам и до недавнего времени о существовании такого издания не было известно. Выявить в архивных документах его удалось Игорю Скочилясу. Он опубликовал фотографию послания $[12$, c. 306$]$ в уменьшенном виде и вкратце изложил суть этого документа. В его задачи не входило библиографическое описание издания и его атрибуция.

Выявленный экземпляр содержит вписанную от руки дату (число и месяц, год воспроизведен печатным способом) - 9 мая 1722 г., собственноручную подпись епископа “Аөанасіи епископъ”, скрепленную восковой печатью под кустодией. Дата вписана в конце документа и свидетельствует о времени подписания грамоты епископом, а оставленные пробельные места для даты объявления универсала остались не заполненными.

Документ напечатан кирилическим шрифтом, основной текст набран в двух столбцах, разделенных наборными украшениями, за исключением интитуляции и конечной части. Украшен пятью ксилографическими инициалами.

Место издания документа не указано. Издание следует атрибутировать типографии Львовского братства. Об этом говорит шрифт, характерный для изданий этой типографии и инициалы, которые использовались во многих ее изданиях. Так, инициал буквы “аз йотированный” с изображением голубя - Св. Духа (самый крупный в этом документе) встречается в изданиях, начиная с первой половины XVII в., например в Анфологионе 1632 г. Доска инициала в издании грамоты изрядно изношена, но так как инициал редко использовался, сохранилась в типографии. Инициал буквы “аз” использовался в Требнике 1720 г. Но, несмотря на то что между изданием книги и грамоты прошло всего два года, в универсале 
доска инициала уже весьма изношена, по сравнению с состоянием двухлетней давности. Инициал буквы “слово” встречается в изданиях Букварей 1671, 1692, 1710 гг., Требника 1720 г. Таким образом, можно с уверенностью утверждать, что послание епископа Афанасия Шептицкого было напечатано в типографии Львовского братства.

Единственный известный на сегодняшний день экземпляр издания универсала 1722 г. Львовского епископа Афанасия Шептицкого о праздновании Юбилея говорит о том, что тираж был разослан по приходам и после использования не сохранялся.

Следующий Юбилейный год, который отмечался во Львовской епархии, был связан с Юбилейным 1775 годом. Его объявил в булле "Salutis nostrae auctor" от 30 апреля 1774 г. папа Климент XIV. Событие должно было начаться в канун Рождества 1775 г., однако понтифик до этого времени не дожил и повторно “Всемирный Юбилей Annus sanctus” был провозглашен в булле "Inscrutabile divinae" от 25 декабря 1775 г. папой Пием VI. Во Львовской епархии Юбилейные мероприятия, связанные с отпущением грехов, проводились после соответствующего объявления “Іувелїона" Львовским епископом Львом Шептицким в 1776 г. В библиографии известна грамота Льва Шептицкого от 30 апреля 1776 г. о проведении “Вселенского Ювелиона”. Впервые описал это издание А. С. Петрушевич в 1884 г. [10, № 187]. Это однолистное издание без указания времени и места печати приводил И. Е. Левицкий [7, с. 14, № 6]. Место нахождение описанного этими библиографами экземпляра сегодня не известно. В каталогах “Львовские издания XVI-XVIII вв.” [6, с. 42, № 201] и “Памятники книжного искусства” А. П. Запаско и Я. Д. Исаевича [5, с. 33, № 2806] издание атрибутировано типографии Львовского братства и указано как разыскиваемое. Можно предположить, что грамота Льва Шептицкого о Юбилейном годе 1776 г. была сходна с соответствующей грамотой Афанасия Шептицкого 1722 г.

Спустя месяц была издана книга “Милостивое льто или Благопотребныхъ моленій къ душеполезному льта Фставленї^ провожденїю собранїе духшвнымъ и мїрскимъ приличное по произволенїю власти напечатасл во врем^ Великаг Іувїлеа". В выходных сведениях указана только дата выхода из печати - 4 июня 1776 г., без обозначения места и типографии. Книга содержит чин Милостивого Лета - “какш Милостивое льто, сирьчь льто шставленї^ начинати”, чин посещения церквей, а также тексты молитв, которые следует читать во время посещения церквей и других событий торжества, тексты “божественных песен”, форму покаяния, “Науку для православных христиан” и “Литанию”.

Единственный известный в библиографии экземпляр впервые был описан Я. Ф. Головацким в 1874 г. с пометкой “Экз. находится у Я. Головацкого” [2, с. 35, № 136]. С 1871 г. он был председателем временной комиссии по устройству Виленской публичной библиотеки и музея и подарил библиотеке значительное число рукописей и старопечатных книг своего собрания. В 1879 г. 
Ф. Н. Добрянский в “Путеводителе по Виленской библиотеке” дает описание книги, как входящей в это собрание [4, с. 50, № 143]. Вошла книга в библиографический указатель И.Е. Левицкого [7, с. 14, № 5]. В 1908 г. А. И. Миловидов при описании старопечатных книг Виленской публичной библиотеки указывает на имеющийся на книге экслибрис: “Въ Виленскую Публичную библіотеку от Я. Головацкаго 1871 г.” [8, с. 119, № 7].

Во время Первой мировой войны значительная часть собрания Виленской публичной библиотеки была эвакуирована в Москву и поступила в Румянцевский музей. Особо ценные и редкие книги вошли в фонд этой библиотеки, в т. ч. и единственный известный экземпляр книги “Милостивое лето". На внутреннюю сторону верхней крышки переплета был приклеен гербовый экслибрис "Библіотеки Императорскаго Московскаго и Румянцовскаго Музея". Этот экслибрис, видимо, наклеен поверх записи Я. Ф. Головацкого. Сейчас эта книга хранится в собрании Научно-исследовательского отдела редких книг Российской государственной библиотеки (Инв. № 3839). Как принадлежащую этому собранию книгу описывали Я. Д. Исаевич и А. П. Запаско [5, с. 33, № 2808; 6, с. 42, № 200], И. Мыцько [9, c. 323, № 185], Ю. Э. Шустова [16, с. 627, № 190]. Таким образом, единственный известный экземпляр книги “Милостивое лето” проделал путь из частного собрания Я. Ф. Головацкого во Львове в Виленскую Публичную библиотеку, а оттуда - в собрание библиотеки Румянцевского музея, ныне - Российской государственной библиотеки.

Книга "Милостивое лето" напечатана форматом in octavo, на 29 ненумерованных листах, украшена наборным орнаментом [3, с. 90, № 35а], двумя заставками, пятью инициалами и одной концовкой. Титульный лист - в рамке из наборных украшений. Несмотря на то, что в книге не указаны место издания и типография, атрибуцию издания типографии Львовского братства установил еще Я. Ф. Головацкий. По шрифтам и орнаментике ее место печати не вызывает сомнений. На титульном листе рукой Я. Ф. Головацкого написано: “Во Львовъ.”. Экземпляр отличной сохранности в современном книге переплете - картонном, обтянутый шпалерной бумагой с растительным орнаментом. Корешок книги подклеен белой бумагой.

На обороте титульного листа напечатана цитата из Ветхого Завета об установлении Юбилейного года: “Возвъстите трубою во всей земли вашей, и Фсвятите льто, пАтьдесятое лЂто, и розгласите Фставленїе на земли всБм живущымъ на ней. Книгъ Левvтскихъ глава, 25. Стих, 9".

В “Чине милостивого лета" говорится о молитвах “въ здравїи” папе Пию VI и “ полностью ектения, а также отмечается, что ее могут "пъти парохи въ своихъ парохїахъ, Чинопоследование необходимо было совершать в каждой из четырех посещаемых церквей и совершается обряд “чрез дній плтьнадесАть, хотАще получити Ḡпущенїе всьхъ грђхювъ своихъ”. 
“Чин посещения церквей” содержит тексты молитв, которые следует читать при входе в церковь (“Возвеселихся о рекших мне”), и в церкви: 1) “ $\omega$

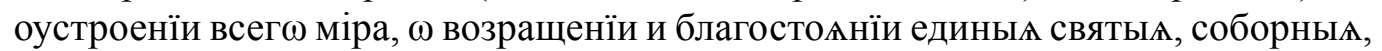
апостолскї церкве”; 2) “Ф разоренїи и искорененї̈ ересей”; 3 ) “Ф соумиренїи и благостолнїи царствъ хрїстїанскихъ”, в которой следует упоминать “кесары нашА” Марию Терезию и Иосифа; 4) “( святьйшом архїереи папь римскомъ” (имя папы не указывалось, лишь в скобках: имярек); “ $\omega$ архїепископъ, епископъ, и всемъ священническомъ чину” (имена архиепископа и епископа не указывались: “(Имярекъ)”). После каждой из этих пяти молитв следовало также прочитать молитвы “Отче наш”, “Богородице Дево радуйся” и Символ веры “Верую в единого Бога”. После этого читалась молитва “Утверди мя, Господи, во истинной сей вере” и молитва перед уходом из церкви "В руце Твоего превеликого милосердия".

Следующий раздел книги включает тексты “Исповеди повседневной”, “Акта скрухъ” (молитвы скорби), “Акта веры”, “Акта надежды” и “Акта любви”. Все эти тексты, за исключением “Акта скрух”, включались в Буквари, издававшиеся в типографии Львовского братства в унийный период в XVIII в. [11, № 6, с. 56].

Большой интерес представляет раздел “Пьсни набожніи на мъссїахъ звычайнїи”. Всего приводятся тексты четырех песен: “Пъснь 1, котора^ спъваетсл

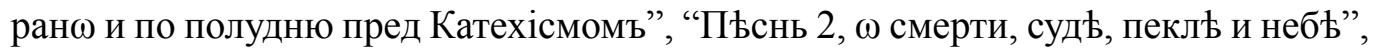
"Пъснь 3, жалю за грђхи. Подобенъ: G горе мнъ! грђшнику сущу”, “Пъснь 4, подобен: Богородице върныхъ Это первая публикация подобных песен в типографии Львовского братства.

Следующий раздел содержит “Форму святыя тайны покаянї^”, а также “Разрђшенїе совершенное, во времл Іовілеа”, т. е. прощение грехов всем, кто исполнил обряд Юбилейного года (“Милостивого года”).

В завершающем разделе книги напечатаны "Наука длА правовђрныхъ хрїстїан” и “Літаніа, къ пресвятьй Девь Маріи Богородицђ”. Текст “Науки длА правовђрныхъ хрїстїан” - краткого катехизиса в форме вопросов и ответов входил в состав многих греко-католических Букварей в XVIII в., причем как в краткой (18 вопросов и ответов), так и в пространной редакции (34 вопроса и ответа) $[17$, с. 50]. По сравнению с аналогичным разделом львовских Букварей 1754 и 1766 гг., содержащем самую полную пространную редакцию катехизиса, в книге "Милостивое лето" содержится 33 вопроса и ответа (не вошел 34-й вопрос), а ответ на 33-й вопрос о том, сколько есть заповедей Божиих, содержит не только указание на то, что их десять, как в Букваре, но и перечисление всех заповедей. Литания Пресвятой Деве Марии также входила в состав многих грекокатолических Букварей XVIII в. (Вильна, 1767, 1782; Почаев, 1799; Супрасль, 1761 ) $[11$, № 2, с. 44; № 3, с. 48; № 37, с. 185 ; № 47, с. 214$]$.

Таким образом, книга “Милостивое лето” содержала не только чинопоследования и молитвы, необходимые для совершения Юбилея (“Annus sanctus”), но и катехитическую часть, имевшую цель просветительскую. 
Грамоты львовских епископов Афанасия и Льва Шептицких от 1722 и 1776 гг., а также книга чинопоследований для совершения Юбилейного года с целью получения отпущения всех грехов представляют собой важные источники в изучении изменений в греко-католической церкви, направленных на сближение с латинским обрядом. Изучение практик празднования Юбилейного года в разных приходах Львовской епархии в связи с этим представляется актуальным с целью понимания, насколько инициированные Львовским епископом мероприятия нового обряда поддерживались и исполнялись. Сохранившийся до наших дней печатный универсал Афанасия Шептицкого от 9 мая 1722 г. и книга “Милостивое лето” 1776 г. позволяют полностью реконструировать процесс совершения Юбилейного года в Львовской епархии в XVIII в. И. Я. Скочиляс назвал эту практику, введенную Афанасием Шептицким, “новым культурным кодом”, который способствовал объединению религиозного сообщества Галицко-Львовской Руси, Подолья и Брацлавщины и открывал новые возможности для диалога униатов с латинскими сообществами [12, с. 308]. Он подчеркивал, что такие окцидентальные заимствования, вводимые не хаотично и спонтанно, а осмысленно конструировались духовными элитами и, с одной стороны, предотвращали культурную ассимиляцию и утрату киевохристианской культурной идентичности в польском и латинском пространстве, с другой, - служили для внешней манифестации единения веры с Римской церковью [12, с. 308].

Изучение источников о Юбилейном годе в греко-католической церкви позволяет глубже понять осуществление и распространение практик применения “нового культурного кода" в обрядовой жизни греко-католиков XVIII в., их готовность к усвоению таких нововведений. Обряд Юбилейного года в этой связи был деликатным введением в силу того, что исполнялся весьма редко - раз в 25 лет, а также сулил отпущение всех грехов, что было практически привлекательным для любого верующего человека. Факт того, что печатные издания, которые должны были обеспечить проведение этого обряда, сохранились весьма плохо (из трех известных дошли до наших дней два, причем в единственных экземплярах), говорит о том, что они были востребованы, тиражи полностью разошлись, а значит и предписания, содержащиеся в этих изданиях, исполнялись. Документов об издании и распространении грамот и книги "Милостивое лето” в архиве братства обнаружить не удалось. Это позволяет сделать вывод о том, что финансирование печатания было осуществлено за счет Львовской епархии, которая также и распространяла эту печатную продукцию по церковным приходам.

Таким образом, рассмотренные грамоты львовских епископов и книга “Милостивое лето" являются важными источниками для изучения изменений в греко-католической церкви в XVIII в., направленных на сближение с латинским обрядом; эортологических практик; изучения репертуара и тематики кириллического книгоиздания в XVIII в.; форм печатной продукции, особенно бланков; грекокатолической катехитической традиции XVIII в.; распространения церковных песен на украинском языке в XVIII в. 


\section{Документ \\ 9 мая 1776 г., Львов. - Универсал Львовского епископа Афанасия Шептицкого о праздновании Юбилейного года}

Археографический комментарий: Текст документа воспроизводится с сохранением букв, вышедших из употребления, титла раскрываются в круглых скобках, выносные буквы вставлены в слова и набраны курсивом, сохранена пунктуация документа и написание слов с заглавных букв. Пробельные места бланка обозначены подчеркиванием, рукописный текст - жирным курсивом.

АӨАНАСІЙ ШЕПТИЦКІЙ. Б(о)жіею и С:(вятого) Өрону Ап(о)ст(о)лскаго м(и) л(о)стію православный. Еп(и)с(ко)пъ Лвовскій, Галицккій, и Каменца Подолскаго. Архімандрита Уневскій.

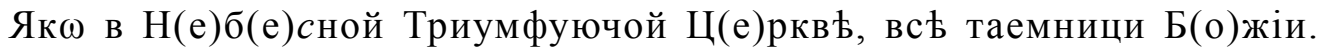
$\widetilde{G J}$ Трїсїлтелнаго единаго Б(о)ж(е)ства вышшим въ первых Серафимским Чиномъ  такожде и на земли в Въюючой Ц(е)ркви С(вя)тои вышиїе чины, дабы ГорнАА съ земнЫМИ СъвоКУПЛАлИСА: И ИншИм ФбАВЛАютъ.

Сътвори тако най Вышшый Пастыр Глава выдима^ всем Вселенской Ап(о) столской Каөолической, церкви Ново избранный ІННОКЕНТІЙ ТринадцАтій, Папа Рымскій, когда нам пастырем благонравїю посльдующым своих Антецесоров, $\widehat{G}$ Верховнъйшаго C:(вятого) Ап(о)c(то)ла Петра идущых. (творивши не токмо с(е)рдца своего $\overline{\mathrm{G}}$ цевскую любов но и всА ськровища, пренайдорогшой Кр(о) ви Хр(и)стовой, и многих заслугъ м(у)ч(е)никовъ и избранныхъ его свой намъ надалъ ЮБЪЛІЕУШ. то ест ЛЬто бл(а)Г(о)д(а)ти и м(и)л(о)сти Б(о)жой. СловеснїА Хр(и)стова стара ювца: съ Ц(е)рквїю Въсточною и Заходною съединенныА, и истиннаго в житїи исправленї^, до Разширенї^ Въры Православно Каөолической: къ соединенїю C:(вятых) Б(о)жіих Ц(е)рквїи: $\omega$ низложенїи ересей: $\omega$ разоренїи противъ Въры Ц(е)ркви Хр(и)стовой нечестивых съвђтовъ: $\omega$ оугашенїи всАких любопрънїи; а запаленА ФгнА любвие и згоды: между Правовърными Цары и КнАsы: $\omega$ избавленїи вслкаго пр(а)в(е)днаго прощенї^ Б(о)же^: яко то: Войны, повЂтрА, и вслкї^ смертоносныА раны бл(а)гоутробїемъ подвыженный възбуждаетъ.

Надлежит теды и намъ Пастыреви, нижшимъ Чиномъ $\omega$ сем извъстити якожъ, Превел:(ебным) Вел:(иким) Пречес:(тным) Сౌцем законнаго и свъцкого стану: ШлАхетне Урожоным Славетным Брацтвом, и Парохїлном: Працовитым людем, Мужескаг(о) и Женскаго Полу, Юношамъ и Дъвам, Богатым и оубогимъ, и всему съсловїю хр(и)стї^нскому в дїецезїи н(а)шой Лвовской, Галицкой, и КамАнцА Подолскаго, изюбрьтающомусл: симъ УнЊверсаломъ юзнаймуемъ и юповЊдаемъ тое бл(а)гопрїлтное Лъто и Тіе Ласкъ Б(о)жїихъ скарбы. Сіе жродло Сౌ КаменА Петра с(вя)т(о)гш на насъ излїлнное, дабысте въ М(о)л(и)твъ прилежной, такожде и Постъ, въ сердци съкрушенномъ, въ смиренїи и кротосты, въ МилостинАхъ, и 
Исповьданї^хъ на сп(а)с(е)нїе душъ своихъ, той ЮБЪЛІЕУШЪ исполнАли, который абы щасливе Фтримав скуток, Таковїе длА исправленї^ подаютсл вам Кондїцїи.

КОНДИЦІЯ ПЕРВАЯ.

ЮБЪЛІЕУШЪ сей быти мает промулгованый, днА — м(е)с(я)ца _— и $\bar{G}$ Фглашенї^ егш Правовърнїи Хр(и)стї^не, чрез единъ тиждень. Понеделокъ, Среду, и ПАтокъ, сухо^денїемъ Б̈правити мают, а трвати през двђ седмици повинен.

КОНДИЦІЯ ВТОРАЯ.

Ц(е)ркви тіи, Первую ве Лвовъ, Катедрђ н(а)шой Еп(иско)пской, Вторую, Успенї^ Прев(вя)ты^ Б(огороди)ци Мъсцкую: Третую С:(вятого) Никола^, на Предградїи Краковскомъ, любъ едного днА, албо в килкохъ днАхъ Фбходити, и тамъ пред Олтаремъ Б(о)жїимъ, О(т)че Н(а)шъ, пАть разъ, и Б(огороди)це Д(е)во, тилкожъ набожне змовивши, тое Ффьровати, за с(вя)тьйшаго Архїере ИННОКЕНТІЯ. ПАПУ Рымскаго, и щасливое ег $\omega$ Ц(е)ркви Б(о)жой раденїе; О разоренїи ересей, Разширенїи же Въры С(вя)той Каөо(л)ической; О оумноженїи Православных Хр(и)стї^ $\mu$ О избавленїи вслкаго Гнъва Б(о)жї^, Войны; ПовътрА морового, и за G̈пущенїе грђхюв своих.

ТРЕТАЯ КОНДИЦІЯ.

По Мъстах Мъстечках, и Селах, где тилко една ест ц(е)рковъ, пре Намъсними Образи, выш реченное, ведлуг постановленА Набоденство трикротне мъютъ виполнити тамечнїи Парохїяне.

ЧЕТВЕРТАЯ КОНДИЦІЯ.

Сповъдники зась мъютъ собъ позволенную, в том тылко разђ, и в двох

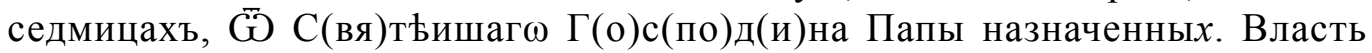

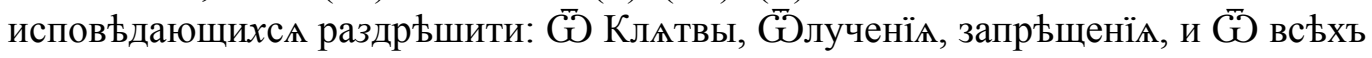
тАжчайших прегрьшенїи, и падежїи: Неточїю Еп(и) $c$ (ко)помъ, но и Самому С(вя) тъйшому Г(о)с(по)д(и)ну, и С(вя)т(о)му Өрону Ап(о)сталскому оудержанных. и сохраненных: еднак же по $\partial$ ты $м$ ФбовАзком, и Кондицїею: ежели такеи виклАтый,

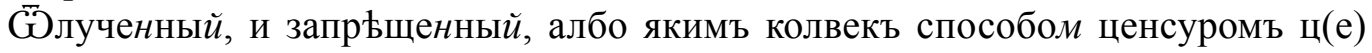
рковным подпаде, и промулгованный: довлетворенїе: сиръчъ: сатисфакцїю оучинитъ, албосА $з$ сторонами оукривжоными згодит. еднак юпроч Законной Профессїи, и на Чистоте шбъщанї^.

ПЯТАЯ КОНДИЦІЯ.

Алмужну ведлугъ можности каждый своей, оубогимъ давати, $\bar{G}$ музикъ, Танцовъ, бесьдъ непотребныхъ, $\bar{G}$ позвовъ, и вшелАкой съ ближным незгоды,

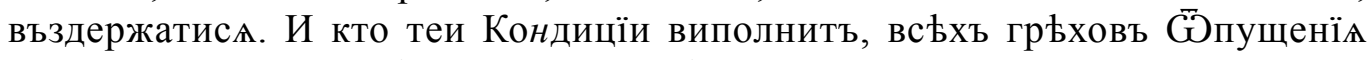
доступитъ, Тилко сповБдатисА и КомунЊю С(вятую) принАти потреба.

Обовґзуемъ притомъ всьхъ Велебныхъ Презвитеровъ, на парохїахъ зостаючихъ, абы по Мъстечках, и Селахъ з людми простшими, Фныхъ сами оучачи тыи м(о)

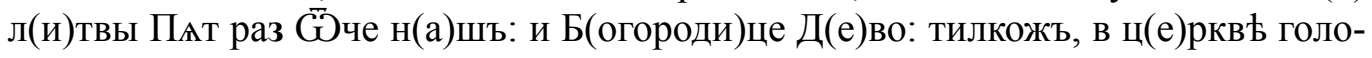
сно мовили, и проводили.

Сей же Оунъверсалъ, абы въ оуслышанїе всъмъ был в Ц(е)рквах, читаный, промолгованный, и до скутку приведеный. Пастирско повельвающе, мъти 
хощемъ. Данъ в Катедръ Н(а)шой Еп(иско)пской Лвовской. ДнА, 9 М(е) $c(я)$ ца, $\underline{\text { мая Року, } 1722 .}$

\section{Аөанасіи епископъ.}

[Восковая печать епископа под кустодией].

ЦГИА Украины, г. Львов. Ф. 129, оп. 4б, д. 3044. л. 1. (Оригинал).

1. Булгаков А. И. Римскокатолические юбилейные годы (по поводу наступающего 1900 года). Труды Киевской духовной академии. 1899. Т. 3. № 10. С. 219-231.

2. Головацкий Я. Ф. Дополнение к Очерку славяно-русской библиографии В. М. Ундольского, содержащее книги и статьи, пропущенные в первом выпуске хронологического указателя славяно-русских книг церковной печати с 1491-го по 1864 год, в особенности же перечень галицко-русских изданий церковной печати. Сборник Отделения русского языка и словесности Академии наук. Санкт-Петербург: Тип. Акад. наук, 1874. Т. 11. № 5. [2], 96 с.

3. Гусева А. А. Идентификация экземпляров украинских изданий кирилловского шрифта второй половины XVI-XVIII вв.: методические рекомендации. Москва: Рос. гос. б-ка, 1997. $138,[1] \mathrm{c}$.

4. Добрянский Ф. Н. Путеводитель по Виленской публичной библиотеке. Вильна: Тип. И. Я. Яловцера, 1879. VIII, 71 с.

5. Запаско Я. П., Ісаєвич Я. Д. Пам’ятки книжкового мистецтва: каталог стародруків, виданих на Україні. Львів: Вид-во при Львівському ун-ті,1984. Кн. 2. Ч. 2: 1765-1800. 125, [2] с.

6. Ісаєвич Я. Д. Львівські видання XVI-XVIII ст.: каталог. Львів, 1970. 50 с.

7. Левицький I. Є. Галицько-руська бібліографія за роки 1772-1800. Записки Наукового товариства ім. Шевченка. Львів, 1903. Т. 52. С. 1-44.

8. Миловидов А. И. Описание славянорусских старопечатных книг Виленской публичной библиотеки (1491-1800 гг.). Отчет Виленской публичной библиотеки и музея за 1907 год. Вильна: Тип. А. Г. Сыркина, 1908. С. 1-160.

9. Мицько І. Видання друкарні Ставропігійського братства та Інституту 1591-1855. 3убрицький Д. Хроніка Ставропігійського братства. Львів: Апріорі, 2011. С. 297-353.

10. Петрушевич А. С. Хронологическая роспись церковных и мирских книг, напечатанных кирилловскими буквами в городе Львове с 1574 до 1880 года. Временник Ставропигийского института на 1885 год. Львов: Тип. Ставропигийского института, 1884. С. 113-133.

11. Рамазанова Д. Н., Шустова Ю. Э. Кириллические Буквари из собрания Научноисследовательского отдела редких книг Российской государственной библиотеки: описание изданий и экземпляров. Москва: Пашков дом, 2018. 336, [3] с.

12. Скочиляс I. Я. Галицька (Львівська) єпархія XII-XVIII століть: організаційна структура та правовий статус. Львів: Вид-во УКУ, 2010. 816 с.

13. Усков Н. Ф. “Annus sanctus”. Православная энцииклопедия. Москва: ЦНЦ “Православная Энциклопедия”, 2001. Т. 2. С. 469-470.

14. Центральный государственный исторический архив Украины, г. Львов. Ф. 201. Оп. 4 . Д. 3044.

15. Шустова Ю. Э. География изданий разрешительных грамот восточных патриархов в XVII в. Историческая география: пространство человека vs человек в пространстве: материаль ХХІІІ междунар. науч. конф. Москва, 27-29 января 2011 г. Москва: РГГУ, 2011. C. $463-467$. 


\section{Науковий щорічник “Історія релігій в Україні”. 2021. Вип. 31}

16. Шустова Ю. Э. Документы Львовского Успенского Ставропигийского братства (1586-1788): источниковедческое исследование. Москва: Рукописные памятники Древней Руси, 2009. 646, [1] с.

17. Шустова Ю. Е. Львівські підручники для навчання грамоти (“Букварь языка славенскаго”) XVII-XVIII століття: православна і греко-католицька традиції. Освіта національних меншин в Україні: історичні традииї, правові засади, сучасні виклики (XX-початок XXI століть). Львів: Інститут українознавства ім. І. Крип’якевича НАН України, 2018. Кн. 1. C. $32-51$.

18. Шустова Ю. Э. Печатные бланки разрешительных грамот восточных иерархов XVII в.: проблемы атрибуции. Монфокон: Исследования по палеографии, кодикологии и дипломатике. Москва: Языки славянских культур, 2017. Вып. 4. С. 639-656.

19. Шустова Ю. Э. Разрешительные печатные грамоты 40-х гг. XVIII в. иерусалимского патриарха Парфения: проблемы изучения и атрибуции // Каптеревские чтения - 9: cб. статей. Москва: ИВИ РАН, 2011. С. 215-243.

20. Thurston H. The Roman Jubilee: History and Ceremonial. London: Sands \& Co., 1925. $\mathrm{XV}, 206 \mathrm{p}$.

\section{References}

1. Bulgakov, A. I. (1899). Rimskokatolichieskiye yubileynye gody (po povodu nastupayushchiego 1900 goda), Trudy Kiyevskoy dukhovnoy akadiemii, т. 3, no. 10, s. 219-231. (in Rus.).

2. Golovatsky, Ya. F. (1874). Dopolnyeniye k Ochyerku sloviano-russkoy bibliografii V.M. Undolskogo, sodyerzhashcheye knigi i statyi, propushchiennyye v piervom vypuskie khronologichieskogo ukazatielia slaviano-russkikh knig tserkovnoy piechati s 1491-go po 1864 god, v osobiennosti zhe pieriechien galitsko-russkikh izdaniy tserkovnoy piechiati, Sbornik Otdielieniya russkogo yazyka i sloviesnosti Akadiemii nauk, Sankt-Pietierburg, t. 11, no. 5, s. 1-96. (in Rus.).

3. Gusieva, A. A. (1997). Idientifikatsiya ekzempliarov ukrainskikh izdaniy kirillovskogo shrifta vtoroy poloviny XVI-XVIII vv.: mietodologichieskiye riekomiendatsiyi, Moskva. (in Rus.).

4. Dobriansky, F. N. (1879). Putievoditiel po Vilienskoy publichnoy bibliotiekie, Vilna (in Rus.).

5. Zapasko, Ya. P., Isaevich, Ya. D. (1984). Pamiatnyky knyzhkovoho mystetstva: kataloh starodrukiv, vydanykh na Ukraini, kn. 2, ch. 2, L'viv. (in Ukr.).

6. Isaevich, Ya. D. (1970). L'vivs'ki vydannia XVI-XVIII st.: kataloh, L'viv. (in Ukr.).

7. Levyts'ky, I. E. (1903). Halyts'ko-rus'ka bibliohraphiia za roky 1772-1800, Zapysky Naukovoho tovarystva im. Shevchenka, t. 52, s. 1-44. (in Ukr.).

8. Milovidov, A. I. (1908). Opisaniye slavianorusskikh staropiechiatnykh knig Vilienskoy publichnoy bibliotieki (1491-1800), Otchiot Vilienskoy publichnoy bibliotieki i muzieya za 1907 god, Vilna, s. 1-160. (in Rus.).

9. Myts'ko, I. (2011). Vydannia drukarni Stavropihiys'koho bratstva ta Instytutu 1591-1855, Zubryts 'ky, D. Chronika Stavropihijs 'koho bratstva, Lviv, s. 297-353. (in Ukr.).

10. Petrushevich, A. S. (1884). Chronologichieskaia rospis' tserkovnykh i mirskikh knig, napiechatannykh kirillovskimi bukvami v gorodie L'vova s 1574 do 1880 goda, Vriemiennik Stavropigiyskogo instituta na 1885 god, Lviv, s. 113-133. (in Ukr.). 
11. Ramazanova, D. N., Shustova, Yu. E. (2018). Kirillichieskiye Bukvari iz sobraniia Nauchno-issliedovatiel'skogo otdiela riedkikh knig Rossiyskoy gosudarstviennoy bibliotieki: opisaniie izdaniy i ekzempliarov, Moscow. (in Rus.).

12. Skochylias, I. Ya. (2010). Halyts'ka (L’vivs'ka) ieparkhiia XII-XVIII stolit': orhanizatsiina struktura ta pravovyi status, L'viv. (in Ukr.).

13. Uskov, N. F. (2001). “Annus sanctus”, Pravoslavnaya encyklopiediya, Moskva, t. 2, s. 469-470. (in Rus.).

14. Tsentralnyi hosudarstvennyi ystorycheskyi arkhyv Ukrayny, h. Lvov, f. 201, op. 4b, d. 3044. (in Ukr.).

15. Shustova, Yu. E. (2011). Geographia izdaniy razreshytielnykh gramot vostochnykh patriarkhov v XVII v., Istoricheskaia geographia: prostranstvo chielovieka vs chieloviek v prostranstvie, Moskva, s. 463-467. (in Rus.).

16. Shustova, Yu. E. (2009). Dokumenty Lvovskogo Uspienskogo Stavropigiyskogo bratstva (1586-1788): istochnikoviedchieskoye issliedovaniye, Moskva. (in Rus.).

17. Shustova, Yu. E. (2018). L’vivs'ki pidruchnyky dlia navchannia hramoty ("Bukvar yazyka slavenskaho") XVII-XVIII stolittia: pravoslavna i hreko-katolyts'ka tradytsii, Osvita natsional'nykh menshyn v Ukraini: istorychni tradytsii, pravovi zasady, suchasni vyklyky (XXpochatok XXI stolittia), L'viv, kn. 1, s. 32-51. (in Ukr.).

18. Shustova, Yu. E. (2017). Piechatnyie blanki razrieszytielnykh gramot vostochnykh iyerarkhov XVII v.: probliemy atributsiyi, Monfokon: issledovanija po palieographiyi, kodikologiyi i diplomatikie, Moskva, t. 4, s. 639-656. (in Rus.).

19. Shustova, Yu. E. (2011). Razrieshytielnyie piechatnyie gramoty 40-kh gg. XVIII v. iyerusalimskogo patriarkha Parpheniya: probliemy izucheniia i atributsiyi, Kapterevskiye chtieniya-9, Moskva, s. 215-243. (in Rus.).

20. Thurston, H. (1925). The Roman Jubilee: History and Ceremonial, London. (in Eng.). 